\title{
Public procurement efficiency in agriculture and forestry in Slovakia
}

\author{
Beata GAVUROVA ${ }^{1}$, David TUCEK ${ }^{2}$, Andrea TKACOVA ${ }^{3}$, \\ Jakub DANKO ${ }^{4}$
}

\begin{abstract}
Agriculture and forestry in Slovakia is a sector that includes the highest number of contract awards in public procurement. The main aim of this article is to identify an influence of selected determinants on public procurement efficiency in agricultural and forestry sector in Slovakia. There are created two basic types of models based on a sample of 291 contracts, which were formed by means of a multiple linear regression in program $R$. The first model examines an influence of variables on public procurement savings that is defined as a rate of the final and probable price of the contract. This model confirms a positive influence of a number of offers on savings' formation, where each next offer increases saving of approximately $8.816 \%$. On the other hand, a subcontractor's presence reduces saving by $19.9 \%$. The second model examines and influence of variables on a number of offers in public procurement. The number of offers in a given sector positively influences a public competition, while there is usually of three offers more than in the negotiating process. However, the number of offers decreases when a contract is financing from the EU funds and when contract specifies a criterion of quality.
\end{abstract}

Keywords: public procurement, agriculture, forestry, saving, multiple linear regression

JEL: H40, H54, Q14, Q18

DOI: $10.24818 / \mathrm{amp} / 2018.30-02$

\section{Introduction}

In Slovakia, a process of consolidation of public finances is under way to reduce the public deficit. This consolidation takes place in two directions, namely increasing the revenue side and reducing the expenditure side of public finances (Ključnikov et al., 2017). The state's effort is to achieve savings in the area of public spending, and the public procurement (PP) system should also be supported

${ }^{1}$ Assoc. Prof. Beata Gavurova, PhD., MBA; Technical University of Kosice; Nemcovej 32, 04001 Kosice; Slovak Republic; e-mail: beata.gavurova@tuke.sk

${ }^{2}$ Assoc. Prof. David Tucek, Ph.D.; Tomas Bata University in Zlin; Nam. T. G. Masaryka 5555; Zlin; Czech Republic; e-mail: tucek@utb.cz

${ }^{3}$ Andrea Tkacova, PhD.; Technical University of Kosice; Nemcovej 32, 04001 Kosice; Slovak Republic; e-mail: andrea.tkacova@tuke.sk

${ }^{4}$ Jakub Danko; Technical University of Kosice; Nemcovej 32, 04001 Kosice; Slovak Republic; e-mail: jakub.danko@tuke.sk 
(Š́ípoš, 2012), (Šípoš \& Klátik, 2013). Its priority role is to ensure efficient spending of state funds, which simplification means achieving public savings (Nemec et al. 2005), (Hanák \& Muchová, 2015). This is only possible when the procurement process is transparent and there is sufficient competition on the supply side (Krasnokutskaya \& Seim, 2011). The size of competition is limited by a number of factors, one of the main factors being the sector in which public procurement is implemented (Vlach \& Ursíny 2007), (Zemanovičová et al. 2010).

Some authors (Rondeau et al. 2016) were focused on the role of other public procurement parameters, auction rules and characteristics of the auction environment. Specifically, they present additional data and discuss the impact of doubling the number of lots offered in order to study the effect of offering "excess supply." In context of that, Baldwin et al. (1997) define in their article about the forest service timber sales that effective bidder collusion will produce winning bids that are low relative to the predictions of a suitable model of non-cooperative behavior, it clearly would not be reasonable to conclude that bidders are colluding solely on the basis of the observation of relatively low winnings bids. A wide range of market conditions can generate low prices when bidders act non-cooperatively (Rajnoha and Lesníková, 2016).

In Slovakia, there is currently sufficient control over the public procurement process provided by the Public Procurement Office. Nonetheless, we are among countries with low bids, suspicions of lack of transparency and corruption in public procurement. From the point of view of the volume of public funds, it is most concentrated in the construction sector. For the period January 2009 - August 2017 in construction it was seven billion euros. The second sector was agriculture and forestry, where over 1.6 billion euros was spent over the same period under review. The third is informatics and communications with an amount of 1.1 billion euros. In terms of the number of public procurement carried out, the order is the opposite. Most contracts were concluded in the agricultural sector (4,538 contracts), in the second place was construction (1,825 contracts) and in the third place was transportation (460 contracts).

PP in transportation and construction is the subject of a study of several foreign and domestic studies (Pavel, 2010), (Hrdlička, 2009), (Antonová et al. 2016), (Shrestha \& Pradhananga, 2010). Most of them focus on the impact of competition, i.e. the number of bids for savings in public procurement. Other determinants are also examined, such as the type of public procurement procedure, subcontracting participation in public procurement, drawing of EU funds, or electronic auction (Tkáčová et al. 2016).

The public sector as shoppers can affect the structure of supply (Fiorentino, 2006), (Millet et al. 2004) consider use e-auction, which should ensure greater competition on the supply side, to be important. In sectors that are associated with high costs of entry into the industry, it is not possible to ensure sufficient competitive environment, which could lead to greater savings in procurement (Shrestha \& Pradhananga, 2010). Quality of competitive environment also depends on a number of offers in a public procurement. Numerous research studies show that growth in 
the number of offers has a positive influence on savings in public procurement (for instance Becerra et. al. 2016; Nipun \& Kwan, 2017; Onur et al. 2012; Kuhlman \& Johnson, 1983). A similar study with the same result on the final cost of public procurement can also be found at (Gilley \& Karels, 1981; Gupta, 2002; Rose, 2016; Gómez-Lobo \& Szymanski, 2001).

\section{Public procurement of forest products and agricultural commodities}

Research studies on the determinants of public procurement efficiency in the agriculture and forestry sectors are rarely available. Public procurement in this sector is examined rather from the point of view of legislation, control of the market for agricultural and forestry products.

Brack's (Brack, 2013) research study provides an interesting overview of public procurement influence on forest products and agricultural commodities. It also points out an insufficient amount of researches in this area and multidimensionality of issues that are related to processes of public procurement. The study focused on a research of a potential to apply public procurement policy on illegal and/or unsustainable agricultural products that are connected with deforestation, such as palm oil, soya, and beef. Many of them belong to a group of public sector purchases (state schools, hospitals, kindergartens, army, etc.). Palm oil and soya are used as a part of bio-fuels. As the evaluations of the European Commission studies show, over $53 \%$ of deforestation in the world during 1990-2008 was caused by agricultural expansion. There are 13 countries that have implemented public procurement policies since September 2013 in order to ensure that public procurement authorities will only use legal and sustainable timber and products made of wood (Austria, Belgium, Denmark, Finland, France, Germany, Japan, Mexico, Netherlands, New Zealand, Norway, Switzerland, and the United Kingdom). Many regional and local authorities, in these and other countries, have their own wood procurement policies. For instance, Netherlands and the United Kingdom have their own criteria. Both countries implemented systems based on independent advisory authorities in order to consider if certification systems are compliant with their criteria of law and sustainability.

Policies of public timber procurement are new tools. Their primary aim is to support a sustainable consumption and production. Also, they may have a significant complementary function in the processes, which are focused on illegal logging, unsustainable procedures of forest management and consequently, related trades. On the other side compatibility of some nationally certified systems in opposition to international agreed frameworks may be an issue. Similarly, equality between certified systems of individual countries, that is included in policies of some countries, is very important. These aspects are mapped by Simula (2016) in detail. Simula points to many issues at international level and confronts numerous proposals for solving potential impacts on public policies' efficiency in this area. It also solves a harmonization issue or larger equivalence between national policies as well as a compatibility of already existing policies with the international legal framework. It is 
supposed that public procurement policies will probably prefer a favor of domestic suppliers, temperate timbers, plantation wood, and large-scale and integrated operations. Small and medium-sized companies, community forests, tropical timber producers, natural timber producers, and others may be disadvantageous. These have obstacles to forests' certification and in obtaining an access to the international sales market.

\section{Materials and Methods}

The aim of the paper is to identify the impact of selected determinants on efficiency in public procurement in the agriculture and forestry sector in Slovakia. Efficiency was investigated through savings in public procurement, and we expressed it in terms of the final and expected cost. The lower the ratio, the greater the savings of public resources.

The ratio of the final and projected price $(\mathrm{Y})$ may be interpreted for procurement purposes in the following ways:

- $\mathrm{Y}>1$ - over-compensation in public procurement,

- $\mathrm{Y}<1$ - savings in public procurement,

- $\mathrm{Y}=1$ - state when the estimated price was won through competition.

The research studies in the area of public procurement were the platform for the selection of efficiency determinants for us. The paper focuses on the number of tenders, the subcontractor's participation and the type of procurement procedure. The paper defines the following hypotheses: price ratio.

H1: The number of tenders has a negative impact on the final and expected

H2: Subcontractor participation has a positive effect on the ratio of final and projected prices.

H3: The tendering procedure has a negative effect on the ratio of the final and the expected prices

H4: The value of the contract negatively affects the number of tenders in the procurement.

In order to verify the established hypotheses, two types of the second order polynomial models in the $\mathrm{R}$ program were constructed, which also allow quantifying the long-term effect of this impact. The first type of model examined the impact of selected variables on savings in public procurement in terms of the ratio of final and projected prices. The second type of model looked at the impact of selected variables on the number of tenders in agriculture and forestry procurement. In this case, it is a classic model of multiple linear regression.

In the case of the first model, the ratio of final and predicted price (Y), which best illustrates the absolute savings or overpayment, is considered as an explanatory variable. The model from which was taken into account the first statistically insignificant variables has the form:

$$
y=\beta_{0}+\beta_{1} \times x_{1}+\beta_{2} \times x_{2}+\beta_{3} \times x_{3}+\beta_{4} \times x_{1}^{2}+\varepsilon,
$$


where $y$ is the ratio of the final and the estimated price, $x_{1}$ is the number of bids, $x_{2}$ is the subcontractor's participation (yes/no) and $x_{3}$ is the type of procedure (tender/negotiation procedure).

Since a quantification of the long-term effect of the number of bids on the size of the savings made by public procurement, there was also included a square of this number to explain the effect of the variable number of bids. As the number of bids can save on average, but this effect is gradually exhausted with the increase in bids. On the contrary, with fewer offers, there is an overproduction, and savings are generated only with a larger number of offers, which may indicate the existence of cartels between a small number of competitors.

In the second model, the number of bids as an explanatory variable was considered, as the determinants that most influence companies to engage in public procurement in this sector were identified, and vice versa, which determinants most discourage these firms from participating in public procurement. It was abstained from the number of bids for a particular contract with a willingness to participate in public procurement. The model that came out after considering the first statistically insignificant variables has the form:

$$
y=\beta_{0}+\beta_{1} \times x_{1}+\beta_{2} \times x_{2}+\beta_{3} \times x_{3}+\beta_{4} \times x_{4}+\varepsilon,
$$

where $x$ is the number of bids, $x_{1}$ is the size of the estimated price, $x_{2}$ is EU funding (yes/no), $x_{3}$ is the quality criterion (yes/no), and $x_{4}$ is the type of procedure (tender/negotiation).

\section{The research sample}

In the Slovakia exist several databases which may be sources of information on public procurement - Public Procurement Notice, Electronic Contracts System, the Uvostat and the database tender.sme.sk. In agriculture and forestry sector, between 1 January 2014 and May 2017, 1,330 contracts were available.

Taking into account the specifics of the individual databases and the objectives of our research, we have selected the database tender.sme.sk. From the contracts, we needed to obtain the following information: estimated cost and the final price of the contract, type of procurement procedure, quality criterion, and EU funding, electronic auction, SME (small and medium enterprise) participation in public procurement, subcontractor participation and number of bids. Based on the required input information requirements, 291 were selected from the total group of contracts, and we were subjected to a follow-up investigation using an appropriate methodology. Table 1 provides a baseline analysis of the sample of data used based on observed determinants of the efficiency of public procurement in agriculture and forestry. 
Table 1. Basic characteristics of the analyzed sample

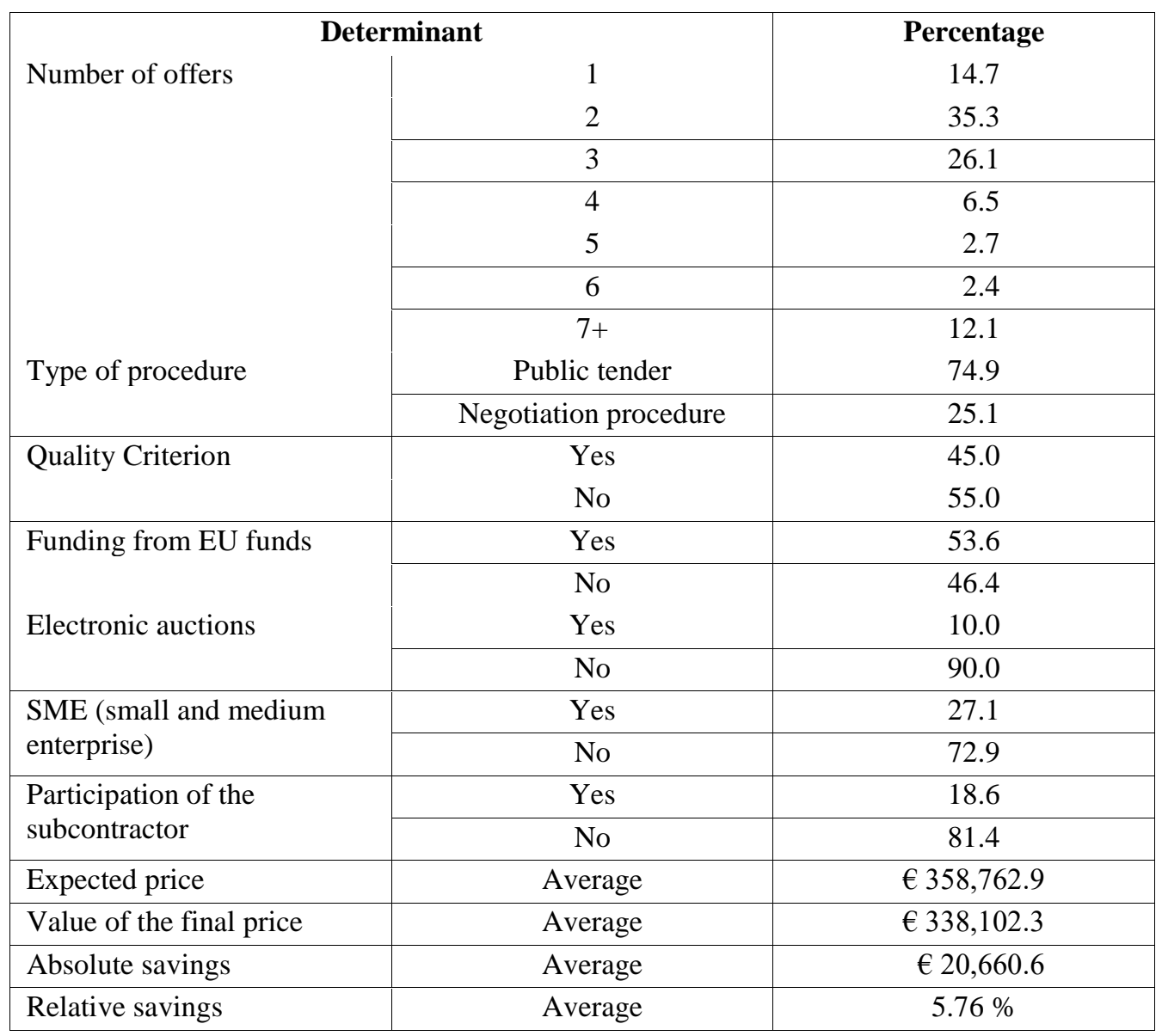

(Source: own contribution)

It is clear from Table 1 that the contracts with two (35.3\%) and three tenders $(26.1 \%)$ are most represented in the sample under study. Nearly $2 / 3$ of the procurement was conducted through a public tender, which should contribute to the transparency of the procurement process. The quality criterion was considered in $45 \%$ of the contracts under review. The over-majority of contracts were funded by the EU funds, but only $10 \%$ was implemented through an electronic action, which is seen as a tool for increasing the savings of public funds. Only in the case of $27.1 \%$ did the procurement take place in a small or medium-sized enterprise. The subcontractor participated in $18.6 \%$ of the sample.

The public procurement has an average positive impact on the creation of savings in public funds in the agriculture and forestry sector. A more detailed analysis of savings in terms of a number of offers is given in Table 2. 
Table 2. Average value and savings achieved by different numbers of tenders in public procurement

\begin{tabular}{|c|c|c|c|c|}
\hline $\begin{array}{c}\text { Number } \\
\text { of offers }\end{array}$ & $\begin{array}{c}\text { Average expected } \\
\text { price }\end{array}$ & $\begin{array}{c}\text { Average } \\
\text { final price }\end{array}$ & $\begin{array}{c}\text { Average } \\
\text { absolute savings }\end{array}$ & $\begin{array}{c}\text { Average relative } \\
\text { savings (\%) }\end{array}$ \\
\hline 1 & $256,772.3$ & $259,489.1$ & $-2,716.84$ & -1.06 \\
\hline 2 & $298,161.5$ & $309,052.1$ & $-10,890.70$ & -3.65 \\
\hline 3 & $419,641.6$ & $424,706.3$ & $-5,064.70$ & -1.21 \\
\hline 4 & $311,960.6$ & $297,470.4$ & $14,490.14$ & 4.64 \\
\hline 5 & $178,568.8$ & $133,172.8$ & $45,395.97$ & 25.42 \\
\hline 6 & $1,386,155.0$ & $651,185.1$ & $734,969.60$ & 53.02 \\
\hline $7+$ & $391,328.9$ & $338,402.1$ & $52,926.80$ & 13.52 \\
\hline
\end{tabular}

(Source: own contribution)

Looking at savings in the selected industry it is possible to identify interesting findings of savings. In the monitored sample, over 1, 2 and 3 offers averaged overtrading. This result can be caused by several factors. One factor may be an incorrect estimate of the estimated contract price which was rated below the market price. This means that such a low price could not offer businesses in the real market. The second reason may be the existence of cartels. Businesses can use this illegal practice in order to divide the market and make the most of the contract. Suspicions of such practices are, for example, in the construction, transport or telecommunications sectors.

\section{Models of the impact of selected variables on savings in public procurement}

On the basis of second-order polynomial regression, the impact of chosen variables on the public procurement result, which was defined as the ratio of final and predicted price, was determined. The first models have demonstrated the statistical insignificance of the use of the EU funds, quality criteria, electronic auctions, and the involvement of SMEs in public procurement. For this reason, a new modified regression model has been constructed for the remaining explanatory variables, i.e. number of tenders, the subcontractor's participation and the type of procedure that proved to be statistically significant. The results of these findings are shown in Table 3. 
Table 3. Second-order polynomial regression results - impact of selected determinants on savings in public procurement

\begin{tabular}{|l|c|c|}
\hline \multicolumn{1}{|c|}{ Explained variable } & \multicolumn{2}{c|}{ Final price as a \% of the estimated price } \\
\hline Explanatory variables & Estimated & Statistical significance \\
\hline Constant & 95.35105 & $<2 \mathrm{e}-16 * * *$ \\
\hline Number of offers & -8.81624 & $6.64 \mathrm{e}-11 * * *$ \\
\hline Number of offers (second power) & 0.43729 & $3.25 \mathrm{e}-09 * * *$ \\
\hline Participation of the subcontractor & 19.9376 & $1.42 \mathrm{e}-06 * * *$ \\
\hline Type of procedure (open competition) & 3.8986 & 0.258 \\
\hline Coefficient of determination & 0.2380 & \\
\hline
\end{tabular}

(Source: own contribution)

On the basis of the model, it was found that if the number of unit bids increases, the final and estimated price drops on average by $8,816 \%$ on otherwise unchanged terms. This means that savings will increase as a result of the increase in the number of offers. The positive regression coefficient at the second power of the number of bids confirms the results in Table 4. On average, savings in public procurement are achieved in this sector, but the course of the function is not constantly decreasing and the savings differ depending on the number of bids. An important role in agriculture and forestry is played by a subcontractor. In the case of the subcontractor's participation, the ratio of final and projected prices was averaged up to $19.9 \%$. This means that on average a $1 / 5$ of the subcontractor's contribution is less than that of a public procurement without a subcontractor. The type of procedure was not a statistically significant variable for this sample.

\section{Impact variability model on the number of bids}

The second model explain the impact of selected variables such as the estimated price, the EU funding, the quality criterion and the type of procedure on the number of tenders in the public procurement was constructed. The second-order polynomial regression results are shown in Table 4. The assembled model demonstrated the statistical significance of the monitored variables. The increase in the expected unit price has a positive impact on the number of offers. If the estimated price rises by $€ 100,000$, the number of offers will increase by 0.6995 . In the case of the type of procedure, it has been shown that the tendering procedure increases the number of tenders by an average of three in comparison with the negotiated procedure. This means that the public tender has a positive influence on competition in public procurement. If the contracts are not funded by the EU funds, the number of tenders increases by an average of 0.9 compared to contracts funded by the EU funds. 
Table 4. Second-order polynomial regression results - impact of selected determinants number of tenders in public procurement

\begin{tabular}{|l|c|c|}
\hline \multicolumn{1}{|c|}{ Explained variable } & \multicolumn{2}{c|}{ Number of offers } \\
\hline Explanatory variables & Estimated regression coefficient & Statistical significance \\
\hline Constant & $-8.680 \mathrm{e}-01$ & 0.1241 \\
\hline Estimated price & $6.995 \mathrm{e}-07$ & 0.685 \\
\hline Funding from EU funds (Yes) & $9.027 \mathrm{e}-01$ & $0.0433 *$ \\
\hline Quality Criterion (No) & $2.789 \mathrm{e}+00$ & $5.79 \mathrm{e}-08 * * *$ \\
\hline Type of procedure & $2.987 \mathrm{e}+00$ & $1.52 \mathrm{e}-07 * * *$ \\
\hline Coefficient of determination & 0.2492 & \\
\hline
\end{tabular}

(Source: own contribution)

This may be due to the EU's higher demands on ISO standards and the certificates available to fewer companies involved in public procurement. This is also the case if the quality criterion is taken into account in public procurement. In this case, the number of tenders tendered on average will fall by 3 offers. This means that the quality criterion reduces the number of tenders in public procurement. On the other hand, the quality criterion should ensure a more efficient spending of funds, which should be reflected in the longer life and usability of the procurement subject.

\section{Results and Discussion}

The goal of public procurement in each sector is to achieve savings in public funds. The agriculture and forestry sector is the number one in Slovakia in terms of the number of public contracts awarded. The amount of public funds spent on this sector through public procurement is second (behind construction). Despite the significance of the sector in the expenditure side of public finances, we are not concerned with research studies to look more closely at the effectiveness of public procurement. Our study declares the results of research in the agriculture and forestry sector in Slovakia for January 2014 - May 2017, which was carried out on a sample of 291 contracts. The results of the analyzed sample of contracts confirmed the fact that public procurement on average has a positive effect on saving, on average over $5 \%$. Through the first assembled model, we found that the number of offers positively affected the size of this savings. With each additional offer, saving is on average $8.8 \%$. This is common in all studies that have shown that competition on the supply side positively impacts on generating public savings. A more detailed analysis of our research sample showed that in the industry, the savings achieved on average for up to four offers. Three overdoses were averaged overweight. This indicates the problem of establishing the presumed price or possible cartels. The result of the first model is confirmed by Hypothesis 1 . The second examined subject was the subcontractor's influence. In the case of subcontractor participation, the growth of the ratio of the final and the presumed price was averaged up to $19.9 \%$, which confirmed the Hypothesis 2. This means that if the procurement took place via 
the subcontractor this would reduce the savings on average by up to $20 \%$. On average, savings have been made, but the subcontractor's margin has fallen to this saving. In the case of a subcontractor, it would be helpful to know also the information on the subcontractors' share of the overall contract and the reasons why they did not participate in the procurement as a direct participant. The reasons mentioned above may already be mentioned, such as, for example, a higher security, a set number of vehicles and others, which may prevent small and medium-sized enterprises from entering the public procurement as a tenderer. In the case of an open competition, the expected impact on the achievement of savings in public procurement was expected. Almost $75 \%$ of all tenders monitored were conducted through a tender. The model did not confirm the statistical significance of this factor and thus reject the Hypothesis 3. In order to achieve sufficient competition on the supply side, it is important to know the factors that affect the number of tenders in the tendering procedure. A second model was designed for these needs. On this basis, it can be argued that the number of tenders negatively affects whether the contract is funded by the EU funds and whether the quality criterion is set. These findings may relate to greater demands on the enterprise itself in terms of the quality of the goods and services that were offered, environmental certificates, or other criteria that the EU may prioritize. This often leads to the exclusion of small farmers from the competition who cannot compete with large agro firms. On the basis of the second model, Hypothesis 4 may be rejected. It has been shown that the rising value of the contract has a slightly positive effect on the number of tenders. This means that there is no decrease in the number of offers under the influence of the growth of the estimated price. The agriculture and forestry sector has its own specifics and differences from other offshoots such as construction, transport or healthcare. Nevertheless, the same law on public procurement is in place to help achieve the savings of public funds. Based on the results of the study, it is possible to identify problems in meeting this goal. The main problem is the low saving, even on average, the overproduction that occurs with a small number of offers in the sector. For one to three bids, there was a significant overcharge, which should be addressed in the future by a new procurement procedure, which should be preceded by a thorough analysis of the market price of the contract. Similar attention should be paid to the prevention of cartels between large agribusinesses. Reduction of savings was also found in the case of subcontracting. The law currently does not impose an obligation to disclose the subcontractors' share of a public contract. For small and mediumsized businesses with a large share of agriculture and forestry, it would be beneficial if the law would set a maximum limit for subcontracting, for example up to $50 \%$ of the total contract work. It is also important to indicate the subcontractor's share of the total value of the contract, thus ensuring a more equitable distribution of public resources. 


\section{Conclusions}

The presented study in the field of agriculture and forestry represents the results on a selected sample of contracts. Nevertheless, it points to the problems of public procurement inefficiency in a low bidding competition. At present, such analyzes are relatively demanding as there are no databases that offer more detailed information on public procurement. Available databases offer the opportunity to analyze the savings achieved or the number of tenders, but not the determinants themselves that have such a significant impact on the outcome of the procurement. Knowledge of these determinants can make a significant contribution to increasing the efficiency of public procurement and may also identify some reasons for a slow consolidation of public spending.

Public procurement studies confirm the positive impact of competition on the supply side of savings in public procurement. This means that the number of offers positively affects the achieved savings of public funds. The analysis of the sample revealed that savings of one to three offers were not on average but, on the contrary, public procurement was overdue. The savings effect appeared on average only on the fourth offer and had a growing tendency. This means ensuring sufficient competition in agriculture is a key to saving public resources.

\section{Acknowledgement}

This publication is an output from the research grants VEGA No: 1/0846/18.

\section{References}

Antonová, B., Chocholáč, J., Drahotský, I. (2016). Analýza závislosti silniční dopravní infrastruktury a přepravních výkonů ve vazbě na HDP české republiky. Scientific papers of the university of Pardubice, 23(36), pp. 5-17.

Baldwin, L.,H., Marshall, R.,C., Richard, J., F. (1997). Bidder collusion at forest service timber sales. Journal of Political Economy, 105(4), pp. 657-99. https://doi.org/10.1086/262089

Becerra, A.D., Androniceanu, A., Georgescu, I. (2016). Sensitivity and vulnerability of European countries in time of crisis based on a new approach to data clustering and curvilinear analysis. Administratie si Management Public, (27), pp. 46-61.

Brack, D. (2013). Controlling trade in agricultural commodities: public procurement policy. Chatham House \& Forest Trends. Energy, Environment and Resources EER PP 2013/03. Retrieved July 21, 2017, from: https://www. chathamhouse.org/sites/files/chathamhouse/home/chatham/public_html/sites/d efault/files/Nov13DBrack.pdf

Fiorentino, L. (2006). Public Procurement and Competition. International Public Procurement Conference Proceedings. Retrieved November 10, 2013, from http://www.ippa.ws/IPPC2/PROCEEDINGS/Article_34_Florentino.pdf

Gavurova et al. (2017). Determinants of public fund's savings formation via public procurement process. Administratie si Management Public, 28: pp. 25-44. 
Gilley, O. W., Karels, G. V. (1981). The competitive effect in bonus bidding: New evidence. The Bell Journal of Economics, 12(2): 637-648. https://doi.org/10.2307/3003578

Gomez-Lobo, A., Szymanski, S. (2001). A law of large numbers: Bidding and compulsory competitive tendering for refuse collection contracts. Review of Industrial Organization, 18(1), pp. 105-113. https://doi.org/10.1023/A: 1026545306923

Gupta, S. (2002). Competition and collusion in a government procurement auction market. Atlantic Economic Journal, 30 (1), pp. 13-25. https://doi.org/ 10.1007/bf02299143

Hanák, T., Muchová, P. (2015). Impact of Competition on Prices in Public Sector Procurement. Procedia Computer Science, 64, pp. 729-735. https://doi.org/ 10.1016/j.procs.2015.08.601

Hrdlička, A. (2009). Veřejné zakázky v oblasti dopravní infrastruktury. Retrieved May 15, 2016, from http://transparency.sk/wpcontent/uploads/2010/01/ akoobstaravatfinal.pdf

Ključnikov, A., Kozubíková L., Sopková G. (2017). The payment discipline of small and medium-sized enterprises. Journal of Competitiveness, 9(2), pp. 45-61. https://doi.org/10.7441/joc.2017.02.04

Krasnokutskaya, E., Seim, K. (2011). Bid preference programs and participation in highway procurement auctions. The American Economic Review, 101(6), pp.2653-2686. https://doi.org/10.1257/aer.101.6.2653

Kuhlman, J. M., Johnson, S. R. (1983). The number of competitors and bid prices. Southern Economic Journal, 50(1) pp. 213-220. https://doi.org/10.2307/ 1058052

Millet, I., Parente, D. H., Fizel, J. L., Venkataraman, R. R. (2004). Metrics for managing online procurement auctions. Interfaces, 34(3), pp. 171-179. https://doi.org/10.1287/inte.1040.0073

Nemec, J., Vítek, L., Meričková, B. (2005). Contracting-out at local government level: theory and selected evidence from the Czech and Slovak Republics. Public Management Review, 7(4), pp. 637-647.

Nipun, A., Kwan, P. (2017). Pricing mergers \& acquisitions using agent-based modeling. economics, Management, and Financial Markets, 12(1), pp. 55-67. https://doi.org/10.22381/emfm12120173

Onur, İ., Özcan, R., Taş, B. K. O. (2012). Public procurement auctions and competition in Turkey. Review of Industrial Organization, 40(3), pp. 207-223. https://doi.org/10.1007/s11151-011-9299-3

Pavel, J. (2010). Analýza vlivu míry konkurence na cenu rozsáhlých staveb dopravní infrastruktury. Politická ekonomie, 58(3), pp. 343-356. https://doi.org/10.18267/j.polek.734

Rajnoha, R., Lesníková, P. (2016) Strategic performance management system and corporate sustainability concept - specific parametres in Slovak Enterprises. Journal of Competitiveness, 8(3), pp. 107-154. https://doi.org/10.7441/ joc.2016.03.07 
Rondeau, D., Courty, P., Doyon, M. (2016). Simultaneous allocation of bundled goods through auctions: assessing the case for Joint Bidding.

American Journal of Agricultural Economics, 98 (3), pp. 838-859.

Rose, S. J. (2016). Income changes during the great recession and the recovery. Journal of Self-Governance and Management Economics, 4(4), pp. 16-26. https://doi.org/10.22381/jsme4420162

Shrestha, P., Pradhananga, N. (2010). Correlating bid price with the number of bidders and final construction cost of public street projects. Transportation Research Record: Journal of the Transportation Research Board, (2151), pp. 3-10. https://doi.org/10.3141/2151-01

Simula, M. (2006). Public Procurement Policies for Forest Products and their Impacts Food and Agriculture Organization of the United Nations. Retrieved July 21, 2017, from http://www.fao.org/forestry/11153-0cd5c4f14302 b06791405f3bb09328f12.pdf

Šípoš, G. (2012). Analýza kvality verejného obstarávania na Slovensku v rokoch 2009-2011. Retrieved May 18, 2016, from http://www.transparency.sk/ wpcontent/uploads/2010/01/2012_Analyza_obstaravania_v_2011.pdf

Šípoš, G., Klátik, P. (2013). Kvalita verejného obstarávania na Slovensku v roku 2012. Retrieved May 18, 2016, from http://www.transparency.sk/wpcontent/uploads/2013/01/TIS-Analyza-VO-2012-1.pdf

Tkáčová et al. (2016). Verejné obstarávanie v dopravnej infraštruktúre Slovenska v rokoch 2010-2015. Scientific Papers of the University of Pardubice. Series D, 23 (38), pp.190-201.

Vlach, J., Ursíny, D. (2007). Ako dobre a správne verejne obstarat'. (1st ed.). Bratislava: Adin, s.r.o.

Zemanovičová, D., Semenčíková, L., Šramelová, S. et al. (2010). Kartelové dohody vo verejnom obstarávaní. Retrieved May 21, 2016, from http://www.antimon. gov.sk/data/files/96_kartelove-dohody-vo-vo.pdf 